UDC 611.018.74: 616.831-005.4-092.9

DOI: $10.21668 /$ health.risk/2018.1.11.eng

\title{
INFLUENCE EXERTED BY NEW PYRIMIDINE DERIVATIVES ON CEREBRAL CIRCULATION AUTO-REGULATION AND VASODILATATING FUNCTION OF VESSELS ENDOTHELIUM IN RATS' BRAINS UNDER CHRONIC HEMIC HYPOXIA
}

\section{A.V. Voronkov, A.S. Lysenko, A.F. Bandura}

Pyatigorsk Medical Pharmaceutical Institute of Volgograd Medical State University, 11 Kalinina avenue, Pyatigorsk, 357532, Russian Federation

Our research goal was to examine influences exerted by new pyrimidine derivatives coded as BLO and BL2 on cerebral hemodynamics auto-regulation parameters and vasodilatating function of vessels endothelium as risk factors causing ischemic and hemorrhagic strokes under chronic hemic hypoxia.

We performed an experiment on white Wistar rats to prove that endothelial dysfunction which evolves under chronic hemic hypoxia leads to disorders in endothelium-mediated mechanisms for cerebral circulation auto-regulation in rats. We modeled hypoxia in animals via granting them free access to $0.2 \%$ sodium nitrite solution instead of ordinary drinking water. Endothelial dysfunction was confirmed as per disorders in vasodilatation and vasoconstriction reactions at intravenous introduction of acetyl choline (0.1 $\mathrm{mg} / \mathrm{kg})$ and methyl ether hydrochloride nitro-L-arginine (10 mg/kg). Cerebral blood flow speed was measured with MM-D-K-Minimax v.2.1. ultrasound Doppler. We assessed cerebral circulation auto-regulation as per compression test results which allowed us to calculate overshoot coefficient and auto-regulation power. Examined pyrimidine derivatives and comparison preparations were introduced orally 60 minutes prior to taking readings. Mexidol doses were calculated on the basis of interspecific recalculation of a maximum daily dose for a man. Nicergoline dose was taken as a most effective one as per literature data.

When new pyrimidine derivatives BLO and BL2 are applied under chronic hemic hypoxia, it causes overshoot coefficient to grow authentically higher than in a negative control group but it doesn't exert any positive influence on collateral reserve parameter, namely auto-regulation power. BLO and BL2 improve endothelium vasodilatating function at intravenous acetylcholine introduction $(0.1 \mathrm{mg} / \mathrm{kg})$ and don't exert any influence on vasoconstricting function at L-NAME intravenous introduction $(10 \mathrm{mg} / \mathrm{kg})$. The examined substance BLO has more apparent pharmacological effects thus exceeding the second substance BL2 and such comparison preparations as Mexidol and Nicergoline in some parameters.

Key words: chronic hemic hypoxia, cerebral hemodynamics auto-regulation, new pyrimidine derivatives, Mexidol, Nicregoline, rats.

Endothelial function disorder is known causing endothelium functional defects [4, to increase ischemic and hemorrhage 5]. Oxidation stress intensifies circulation strokes risks considerably, and such strokes disorders, damage to vessels endothelium, can cause death or grave disability [1-3]. changes in nitrogen oxide production, negOxidation stress activation which occurs ative rheological changes etc., and it detedue to various hypoxia types, including riorates a basic pathological process [6-8]. hemic one, is a basic pathogenetic factor Endothelial dysfunction leads to disorders

(C) Voronkov A.V., Lysenko A.S., Bandura A.F., 2018

Andrei V. Voronkov - Doctor of Medical Sciences, Associate Professor, Head of Pharmacological Department with Clinical Pharmacology course (e-mail: prohor.77@mail.ru; tel.: +7 (879) 332-92-66).

Aleksandr S. Lysenko - post-graduate student at Pharmacological Department with Clinical Pharmacology course (e-mail: a.s.lysenko@bk.ru; tel.: +7 (962) 42-42-161).

Aleksandr F. Bandura - Candidate of Pharmaceutical Sciences, a lecturer at Pharmacy Organization and Economics Department (e-mail: alex_paris@mail.ru; tel.: +7 (918) 824-34-07). 
in cerebral blood flow auto-regulation with its main function being maintenance of constant flow speed in cerebral vessels [914]. Necessity to find means aimed at minimizing risks of pathologies related to disorders in cerebral hemodynamics autoregulation under cerebral hypoxias is a vital and interesting task..

Our research goal was to examine influence exerted by new pyrimidine-4-on derivatives, BL0 and BL2, on cerebral circulation auto-regulation and vasodilatating function of cerebral vessels endothelium, our research objects being rats' brains under chronic hemic hypoxia.

Data and methods. We performed our experiment on 60 male Wistar rats with body weight being equal to 200-250 grams. Animals were divided into 6 groups $(n=10)$; the first group was an intact one; the second group included animals with chronic hemic hypoxia; animals with chronic hemic hypoxia from the 3rd group were given new pyrimidine-4-on derivative, BL0 (50 mg/kg): animals with chronic hemic hypoxia from the 4th group were given new pyrimide-4-on derivative, BL2 (50 $\mathrm{mg} / \mathrm{kg}$ ); animals with chronic hemic hypoxia from the 5 th group were given a reference medication, Mexidol (74 $\mathrm{mg} / \mathrm{kg}$ )[15]; animals with chronic hemic hypoxia from the 6th group were given another reference medication, Nicergoline (10 mg/kg).

We modeled chronic hemic hypoxia via granting the experimental animals free access to $0.2 \%$ sodium nitrite solution instead of ordinary water, during 14 days [9, $16]$.

New examined pyrimidine-4-on derivatives and two reference medications were introduced orally 60 minutes prior to parameters reading. Mexidol dose was calculated basing on interspecific recalculation of a maximum daily dose for a man. Nic- ergoline dose was taken as the most effective one as per literature data [17].

After two weeks of chronic hemic hypoxia formation, we assessed functionality of brain vessels endothelium $[11,18]$.

Brain vessels ability to regulate themselves was assessed as per carotid test results. Overall carotid artery compression results in drastic decrease in blood flow speed, and its decompression, to a drastic increase in linear speed. Data obtained via this test allow to assess auto-regulation reserves as per calculated coefficients: overshoot coefficient (OC) (1) and autoregulation power (2):

$$
\begin{gathered}
\hat{\mathrm{E}} \hat{\mathrm{I}}=\frac{V_{3}}{V_{1}}, \\
\tilde{\mathrm{N}} \mathrm{A} Đ=\frac{V_{3} V_{2}}{V_{1}^{2}},
\end{gathered}
$$

where $V 1$ is cerebral blood flow speed before compression; $V 2$ is cerebral blood flow speed during compression; $V 3$ is cerebral blood flow after deocclusion.

We treated data statistically with Microsoft Office Excel 2010 standard software. Validity was assessed as per MannWhitney criterion.

Results and discussion. As per compression test results, overshoot coefficient was equal to $1.01 \pm 0.02$ in the control group and it was authentically lower than the same parameter in the intact group where it was equal to $1.25 \pm 0.03$. Overshoot coefficient values in animals' groups which were given new pyrimidine-4-on derivatives BL0 and BL2 60 minutes prior to parameters reading were authentically higher than in the control group and authentically lower than in the intact group; they were also higher than in the group which was given Mexidol, one of the reference medications. Overshoot coefficient values in animals which were given the reference medications (Mexidol and Nic- 
ergoline) tended to grow but didn't have any significant discrepancies from the control group parameters (Figure 1).

Auto-regulation power was equal to $0.61 \pm 0.041$ in the control group which was authentically lower than in the intact group where this parameter amounted to $0.80 \pm 0.043$. Auto-regulation parameters in animals which were given the examined substances BL0 and BL2, as well as Mexidol (one of the reference medications), didn't have any authentic discrepancies

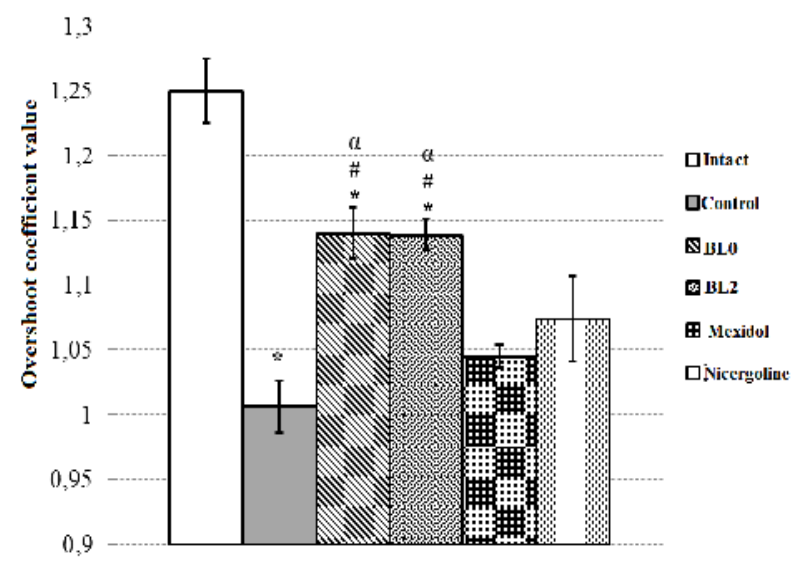

Figure 1. Overshoot coefficient value in the experimental groups.

Note: * means authentic against the intact group ( $<<0.05)$; \# means authentic against the control group $(\mathrm{p}<0.05) ; \alpha$ means authentic against the group which was given Mexidol $(\mathrm{P}<0.05)$

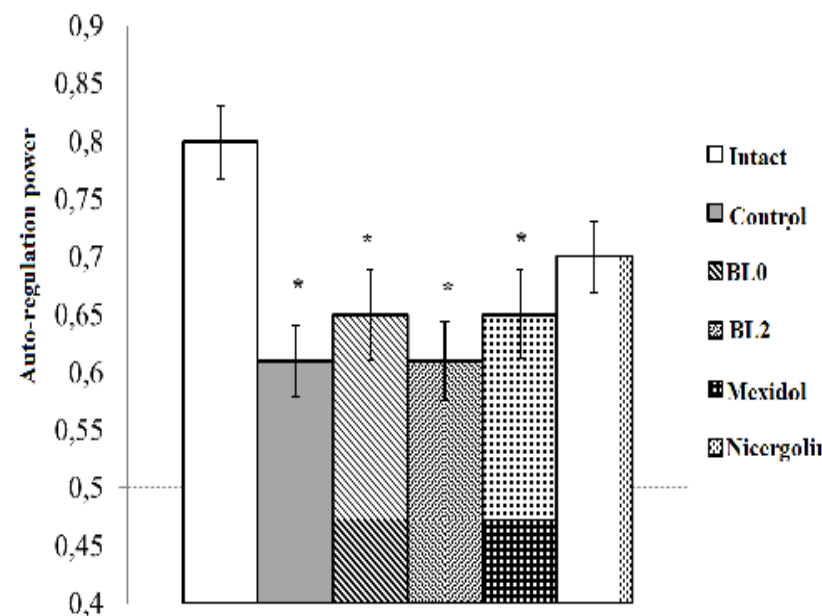

Figure 2. Values of cerebral hemodynamics auto-regulation power in the experimental groups. Note: * means authentic against the intact group $(\mathrm{P}<0.05)$ from the control group and were lower than the same parameter in the intact group. Auto-regulation power parameter in animals which were given Nicergoline (another reference medication) didn't have any authentic discrepancies either from the control group, or the intact group (Figure 2).

Research on brain vessels reactivity performed with ultrasound Doppler revealed that vasodilatation reaction to intravenous introduction of acetyl choline ( 0.1 $\mathrm{mg} / \mathrm{kg}$ ) was authentically lower in the control group than in the intact one and amounted to $12.7 \% \pm 1.58$, this parameter being equal to $23.7 \% \pm 2.14$ in the intact group. The examined new pyrimidine-4-on derivatives BLO and BL2, as well as the reference medications Mexidol and Nicergoline, authentically enhanced vessels reaction to intravenous introduction of an endogenous nitrogen oxide modulator against the control group. We should note that growth in cerebral blood flow amounted to $35.2 \% \pm 2.09$ among animals which were given Mexidol, and it was authentically higher than the same parameter in the intact group. Vasodilatation reaction in rats which were given BL0 also tended to be higher than in the intact group, but this parameter didn't differ from that of the intact group authentically; however, it was lower than in the group which was given Mexidol and amounted to $28.0 \% \pm 1.81$.

A decrease in cerebral blood flow caused by intravenous L-NAME introduction $(10 \mathrm{mg} / \mathrm{kg})$ amounted to $-11.5 \% \pm 1.43$, in the control group and it was authentically lower than in the intact group where this cparameter amounted to $-22.0 \% \pm 1.44$. Vasoconstriction reaction in animals which were given BL0, BL2, and Mexidol, was authentically lower that in the intact group and didn't have any authentic discrepancies from the control group. A reduction in cerebral blood flow speed among animals 
which were given Nicergoline amounted to $-21.0 \% \pm 2.1$ after e-NOS inhibitor intravenous introduction, which was authentically higher than in the control group and didn't have any discrepancies from the intact group (Figure 3).

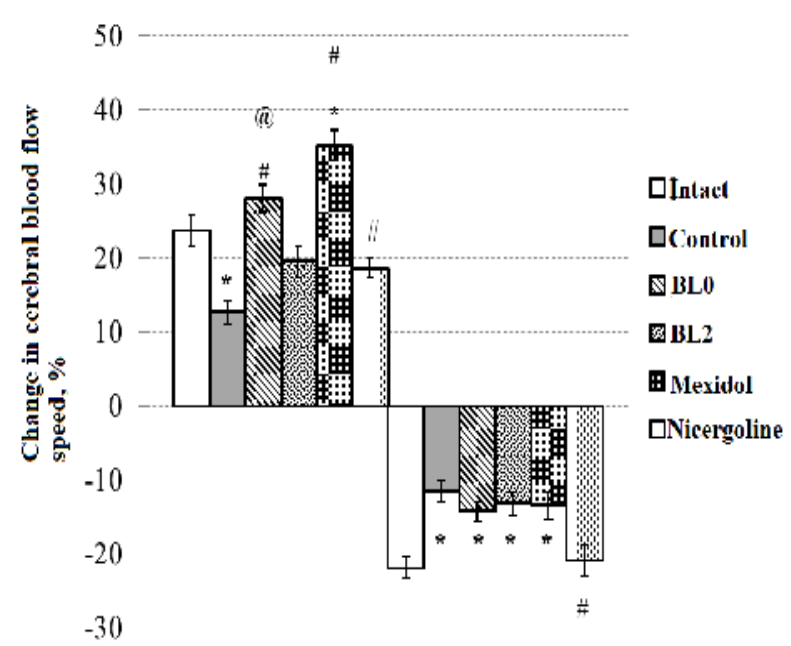

Figure 3. \% of change in cerebral blood flow speed as a reaction to acetyl choline and L-NAME. Note: * means authentic against the intact group $(\mathrm{P}<0.05)$; \# means authentic against the control group $(\mathrm{P}<0.05)$; @ means authenticc against the group which was given Mexidol $(\mathrm{P}<0.05)$.

A $50 \%$ decrease in vasodilatation reactions after acetyl choline was introduced intravenously, and vasoconstriction reaction, after L-NAME was introduced intravenously, in the control group against the intact group under chronic hemic ischemia proves there is a disorder in endotheliummediated cerebral hemodynamics autoregulation mechanisms allowing for an authentic reduction in overshoot coefficient and auto-regulation power.

New pyrimidine-4-on derivatives BL0 and BL2 to the same extent increase overshoot coefficient against the control group thus being more efficient than the reference medications. The examined substances and the reference medications didn't exert any positive influence on autoregulation power. BL0, BL2, Mexidol and Nicergoline restored vasodilatating endothelium function after acetyl choline intravenous introduction in comparison with the control group, and in spite of Mexidol being more efficient, this new pyrimidine derivative, $\mathrm{BL} 0$, is not much inferior to it.

So, according to all the obtained data, new pyrimidine-4-on derivatives, BL0 and BL2, have positive influence on cerebral hemodynamics auto-regulation and endothelium vasodilatating function; they are more efficient than the reference medications as per some parameters, and it calls for their further examination in terms of health risk assessment and minimization.

\section{References}

1. Vatter H., Konczalla J., SeifertV. Endothelin related pathophysiology in cerebral vasospasm: what happens to the cerebral vessels? Acta Neurochirurgica Supplementum, 2011, vol. 110, pp. 177-180.

2. Peterson E.C., Wang Z., Brits G. Regulation of Cerebral Blood Flow. International Journal of Vascular Medicine, 2011, vol. 2011, Article ID 823525, 8 pages. DOI: $10.1155 / 2011 / 823525$

3. Lin A.L., Fox P.T., Yang Y., Lu H., Tan L.H., Gao J.H. Time-dependent correlation of cerebral blood flow with oxygen metabolism in activated human visual cortex as measured by fMRI. Neuroimage, 2009, vol. 1, no. 44, pp. 16-22.DOI: 10.1016/j.neuroimage.2008.08.029

4. Voronkov A.V., Pozdnyakov D.I., Mamleev A.V. Izuchenie vazodilatiruyushchei i antitromboticheskoi funktsii endoteliya sosudov golovnogo mozga krys na razlichnykh modelyakh ego ishemicheskogo povrezhdeniya [The study of the vasodilating and antithrombotic function 
of the endothelium of brain vessels of rats in various models of ischemic injury]. Sovremennye problem nauki i obrazovaniya, 2015, no. 5, pp. 264 (in Russian).

5. Kotova O.V. Distsirkulyatornaya entsefalopatiya: novye vozmozhnosti kombinirovannoi terapii [Circulatory encephalopathy: new opportunities of the combination therapy]. Effektivnaya farmakoterapiya, 2013, no. 32, pp. 64-70 (in Russian).

6. Tyurenkov I.N., Voronkov A.V., Slietsans A.A., Dorkina E.G., Snigur G.L. Antioksidantnaya terapiya endotelial'noi disfunktsii [Antioxidant therapy of endothelialdysfunction]. Obzory po klinicheskoi farmakologii i lekarstvennoi terapii, 2013, vol. 11, no. 1, pp. 14-25 (in Russian).

7. Tyurenkov I.N., Voronkov A.V., Slietsansi A.A., Dorkina E.G. Zavisimost' mezhdu antioksidantnym deistviem flavonoidov i ikh vliyaniem na vazodilatiruyushchuyu funktsiyu endoteliya $\mathrm{v}$ usloviyakh endotelial'noi disfunktsii [Relationship between the antioxidant effect of flavonoids and their effect on the vasodilating function of endothelium under endothelial dysfunction conditions]. Eksperimental'naya i klinicheskaya farmakologiya, 2010, vol. 73, no. 10, pp. 14-16 (in Russian).

8. Tyurenkov I.N., Voronkov A.V., Slietsans A.A. Rol' endotelial'noi disfunktsii v razvitii sosudistykh oslozhnenii sakharnogo diabeta [Role of endothelial dysfunction in the development of vascular complications of diabetes]. Patologicheskaya fiziologiya i eksperimental'naya terapiya, 2013, no. 2, pp. 80-84 (in Russian).

9. Voronkov A.V., Lysenko A.S. Vliyanie khronicheskoi gemicheskoi gipoksii na funktsiyu endoteliya i pokazateli autoregulyatsii tserebral'noi gemodinamiki u krys [Influence of chronic hemic hypoxia on endothelial function and indicators of autoregulation of cerebral hemodynamics in rats]. Mezhdunarodnyi nauchno-issledovatel'skii zhurnal, 2016, vol. 46, no. 4-5, pp. 8588 (in Russian).

10. Kozlovskii V.I. Mekhanizmy regulyatsii koronarnogo krovotoka, oposredovannoi endotelial'nymi sosudorasshiryayushchimi faktorami: monografiya [Mechanisms for coronary blood flow regulation mediated with endothelial vasodilatory factors: monograph]. Grodno: Gr. GMU Publ., 2011, 216 p (in Russian).

11. Voronkov A.V., Lavinskii N.G., Arl't A.V., Lysenko A.S. Otsenka autoregulyatsii tserebral'noi gemodinamiki u krys samok pri endotelial'noi disfunktsii, vyzvannoi nedostatochnost'yu polovykh gormonov [Assessment of cerebral haemodynamicautoregulation of female rats in condition of endothelium dysfunction caused by insufficiency of reproductive hormones]. Zhurnal nauchnykh statei Zdorov'e i obrazovanie v XXI veke, 2016, vol. 18, no. 3, pp. 107-111 (in Russian).

12. Tovazhnyanskaya E.L., Dubinskaya O.I., Bezuglaya I.O. Narushenie autoregulyatsii mozgovogo krovotoka kak faktor razvitiya mozgovykh distsirkulyatsii pri sakharnom diabete 2gotipa [Autoregulation Disorders of Cerebral Blood Flow as a Factor of Cerebral Dyscirculations Development at Diabetes Mellitus Type 2]. Mezhdunarodnyi nevrologicheskii zhurnal, 2012, vol. 50, no. 4, pp. 43-47 (in Russian).

13. Chen B.R., Kozberg M.G., Bouchard M.B., Shaik M.A., Hillman E.M. A critical role for the vascular endothelium in functional neurovascular coupling in the brain. J. Am. Heart Assoc, 2014, no. 3, e000787. DOI: 10.1161/JAHA.114.000787.

14. De Vriese A.S., Verbeuren T.J., Van de Voorde J., Lameire N.H., Vanhoutte P.M. Endothelial dysfunction in diabetes. British Journal of Pharmacology, 2009, vol. 130, no. 5, pp. 963-974.

15. Tyurenkov I.N., Voronkov A.V., Slietsans A.A., Snigur G.L. Vliyanie meksidola i sulodeksida na uroven' spetsificheskikh markerov razvitiya endotelial'noi disfunktsii u zhivotnykh s eksperimental'nym sakharnym diabetom [Effects of Mexidol and Sulodexide on the Level of Specific Markers of Endothelial Dysfunction in Animals with Experimental Diabe- 
tes Mellitus]. Eksperimental'naya i klinicheskaya farmakologiya, 2012, vol. 75, no. 5, pp. 14-16 (in Russian).

16. Ivanova A.S., Peretyatko L.P., Demidov V.I., Nazarov S.B. Vliyanie oksida azota na morfologiyu platsenty i aktivnost' platsentarnykh makrofagov pri neoslozhnennoi beremennosti $\mathrm{v}$ eksperimente [Effect of nitric oxide on the morphology of the placenta and the activity of placental macrophages during uncomplicated pregnancy in the experiment]. Arkhivpatologii, 2014, no. 4, pp. 35-38 (in Russian).

17. Onbysh T.E., Pogorelyi V.E., Makarova L.M., Slyun'kova N.E. Vliyanie nitsergolina na autoregulyatornye reaktsii sosudov mozga pri gipoperfuzionnykh narusheniyakh mozgovogo krovoobrashcheniya [Impacts exerted by Nicergoline on cerebral vessels auto-regulatory functions under hypoperfusional disorders in cerebral circulation]. Razrabotka, issledovanie $i$ marketing novoi farmatsevticheskoi produktsii: sbornik nauchnykh trudov [Development, examination, and marketing of new pharmaceuticals: scientific works collection]. Pyatigorsk, Pyatigorskaya GFA Publ., 2005, vol. 60, pp. 401-402 (in Russian).

18. Tyurenkov I.N., Voronkov A.V. Metodicheskii podkhod k otsenke endotelial'noi disfunktsii v eksperimente [A new methodological approach to the experimental estimation of endothelial dysfunction]. Eksperimental'naya i klinicheskaya farmakologiya, 2008, vol. 71, no. 1, pp. 49-51 (in Russian).

Voronkov A.V., Lysenko A.S., Bandura A.F. Influence exerted by new pyrimidine derivatives on cerebral circulation auto-regulation and vasodilatating function of vessels endothelium in rats' brains under chronic hemic hypoxia. Health Risk Analysis, 2018, no. 1, pp. 98-103. DOI: 10.21668/health.risk/2018.1.11.eng

Received: 17.01 .2018

Accepted: 12.03 .2018

Published: 30.03.2018 